\title{
James L. Harner: In Memoriam
}

Edited by Laura Estill

\section{Laura Estill ${ }^{*}$}

\section{Introduction}

Although it seemed like Jim Harner knew everybody in Shakespeare studies, this was not the case. Jim's scholarly work, however, has affected all Shakespeareans, by changing how we can research Shakespeare. He edited the World Shakespeare Bibliography (www.worldshakesbib.org) for thirty years and compiled the MLA's Literary Research Guide. Jim's legacy, however, goes beyond his superb scholarship. Jim was a noted collector of miniature books and a devoted husband, father, and grandfather. This special cluster for Multicultural Shakespeare gathers some fond memories of Jim, who is greatly missed.

\section{For World Shakespeare: In Memory of Jim Harner, the World's Greatest Shakespeare Bibliographer}

\section{Lingui Yang ${ }^{* *}$}

"I am Sam; Sam I am...."

Dr. Seuss's Green Eggs and Ham was the first American Christmas gift my daughter received after she landed on the new continent at four years old, and it was from Jim. It became her best bedtime poem ever after and has been a treasured item since her elementary years.

Jim's gift was not the only parenting tool for me, then a young father, who was working as his assistant at the World Shakespeare Bibliography (WSB). He taught the youngsters I brought to the office how to find fun in book boxes, turning my embarrassing moment into a babysitting lesson. Imagine how mad a boss could be to find his underlings making his office a playhouse for children.

\footnotetext{
* St. Francis Xavier University, Canada.

** Donghua University, Shanghai, China.
} 
That's what I did in the late 1990s, but luckily I didn't have an angry boss. In the third semester of my doctoral program, I had to run to the bibliography office since my laptop broke, in order to complete a paper that was due for my evening class. And worse yet, it was my family's turn for afterschool babysitting, shared among a few married graduate student families, and my wife was not able to get home early enough to take over. Consequently, I took the little ones (four or five years old) to the office after hours. While they merrily chased after one another among the book stacks in the bibliography library at the back of the large office of several non-partitioned rooms, Jim came in for a book he would take on his next day's travel, totally unexpected by me and the boisterous kids. I mumbled, trying to explain the situation, but he reassured me with a benign smile that relieved my anxiety. He told me to carry on my writing, while he led the giggling party to the front section of the office. There he taught them how to fold and unfold book boxes, which they piled on top of each other and turned into castles where they played hide-and-seek, as he laughed and left.

For me, Jim Harner was never a boss, but a venerated professor and the world's greatest Shakespeare bibliographer, and yet at that moment even the image of the endowed professor and award-winning bibliographer turned into a funny grandfather figure that my daughter still loves to talk about, her fond memories of Jim starting from Green Eggs and Ham. We picked another Dr. Seuss book for his retirement in November 2014, wishing him a happy life at his new home in Virginia and imagining him reading You're Only Old Once: A Book for Obsolete Children with laughter. And for us, his child-like laughs are never obsolete.

Jim's amiable and kindly smiles are more valuable than any material gifts he had given. I took great courage from his smiles: courage to meet academic and familial challenges during my stay as an international student in the United States. His encouragement has boosted my progress as a Shakespeare scholar for two decades.

We first met in Los Angeles in 1996, although we had exchanged correspondence for my contributing to the WSB several years before. His smiling greeting made our first meeting a rendezvous of old friends and lessened my nervousness as a beginning participant in big scholarly events such as the International Shakespeare Association's (ISA) World Shakespeare Congress (WSC) and the Shakespeare Association of America (SAA) Conference. He invited me to the WSB's luncheon at that year's joint event of the WSC and SAA's annual conference, at which he used to hold a luncheon or dinner party for his international correspondents and demonstrated how to use the WSB at a reserved exhibition desk every year (SAA) or every five years (WSC). The last WSC we both attended was the $9^{\text {th }}$, held in Prague in 2011, when I became a member of the ISA's executive committee, upon which he congratulated me 
with great pride. I missed him at the $10^{\text {th }}$ WSC (Stratford-upon-Avon and London, $31^{\text {st }}$ July- $6^{\text {th }}$ August, 2016), for which I served on the Congress Committee: Jim had passed two months before the event.

At the 2011 WSC, Jim insisted on treating me with a memorable Czech dinner at a restaurant overlooking the Vltava in addition to the group luncheon for the WSB's Committee of International Correspondents. To this day, I am still not able to believe that was the last WSC dinner with him. At many other dinners, from holiday receptions, such as Christmas and Thanksgiving at restaurants to private occasions at his home, I enjoyed the opportunity to share his enthusiasm for food as much as he called himself a foodie.

Jim's humor and wisdom provided me with no less food for intellectual and academic development. For the last twenty years, I always feel that I'm the luckiest to be with him or to have him with me at his or my great moments. Since I entered Texas A\&M University as a doctoral student in 1997 and later as a postdoc on the faculty, I witnessed him win several national and international awards for scholarly achievements, such as the American Publishers Award for his MLA Literary Research Guide and the Besterman Medal and Besterman/McColvin Medals for editing WSB Online.

Jim was always on my side and gave me a pat on the back to express his pride for every occasion when I was recognized, such as the Conference for College Teachers of English "Best Shakespeare Paper," Texas A\&M Distinguished Graduate Research Award, and other promotions I received even after I left the school. He had every reason for celebration as he played a significant role in practically all my achievements in Shakespeare studies as a voluntary reviewer and virtually the first reader before I sent out my papers for publication.

We kept exchanging academic and personal updates, beyond his annual Christmas letter and my trivial requests for paper reading, although we missed each other for years after I left Texas A\&M. When a scholarship opportunity allowed me to visit with him again in June 2014 through June 2015, I was eager to see him at the bibliography office. And there and then, I received a special gift. Of all the scholarly and personal support he gave me, this is extremely precious because it connects my relationship with Jim back to the very words of "world Shakespeare" as this gift is associated with our mutual experiences of the World Shakespeare Bibliography and the World Shakespeare Congress.

On $12^{\text {th }}$ of September 2014, before the lunch meeting with him and Professor Laura Estill, his successor as the editor of the WSB, I marveled as they handed me the WSB's copy of the poster for the WSC in Los Angeles. Thanks to the snapshot by Dr. Krista May, the current Associate Editor of the WSB, the historic occasion was appropriately recorded (see the picture below). The poster is a framed duplicate of the "Shakespeare Dude," painted by Kevin Chadwick and used as the Bard's image with a chic look of a cool guy of the 1990s in a modern shirt and sunglasses. Jim knew that I liked the poster, ever regretting 
not being able to get a copy when I attended the conference where I met him for the first time. His copy had been on the wall of the WSB office for almost twenty years before he generously conferred it on me, and now it is on the wall of my office in Shanghai.

It was at the lunch meeting, also, that I was informed of Jim's final decision on the date of his retirement. I was fortunate to have attended his retirement reception, hearing him laughing even when he talked about his surgery. I managed to keep in close contact with him even though I was busier than ever at my home institution in Shanghai. Our last contact was in March 2016, when he told me from his home in Virginia that he liked the blanket I sent him earlier, which he put to immediate use as it was still cold in the north, and that Priscilla Meserole, the former Technical Editor of the WSB, a cordial friend, was going to visit him for his $70^{\text {th }}$ birthday. I wish I had been able to be there to see his smiles again before the inevitable struck all of us who loved him.

As Shakespeare's melancholic Jaques asserts, not without pessimism,

All the world's a stage,

And all the men and women merely players;

They have their exits and their entrances,

And one man in his time plays many parts. (As You Like It 2:7:139-142)

Memories of Jim's smiles and laughs remind me that we see the speech optimistically as he played extremely well all the many parts in his time, especially with the magnificence of the last twenty years that I have witnessed. What is yet more personally pertinent to me is that these parts have extended so deeply into my life and career. He was responsible for bringing me to North America two decades ago and had played a great role in my scholarly development. The most important, of course, is his unwavering support that enhanced my growth in Shakespeare studies. So, for me he is a great mentor, advisor, and colleague, as well as the world-renowned Shakespeare bibliographer. But all in all, he was a friend, who was always willing to "raise me up to more than I can be." Even a reminiscence of his smile gives me strength till this moment. 


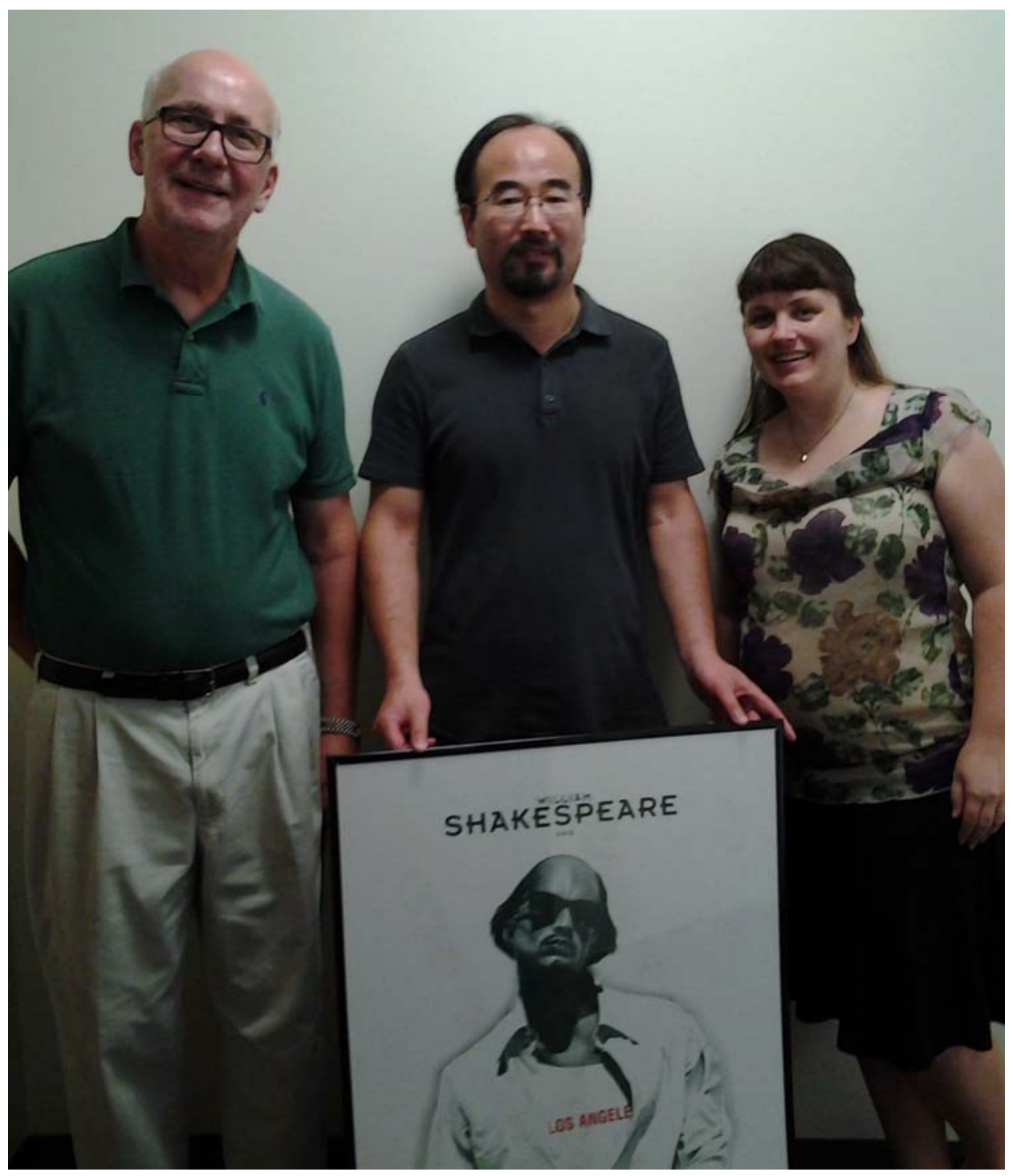

Jim Harner, Lingui Yang, and Laura Estill, 12 Sept. 2014 Photo Courtesy of Krista May 


\section{Friendship@JimHarner.edu}

\section{Monica Matei-Chesnoiu*}

It was excruciatingly hot on that August 1998 day when my flight landed at the small airport in College Station, TX. The newly appointed Fulbright Scholar was just about to start her period of research at the World Shakespeare Bibliography, Texas A\&M University English Department. The expectations were high, but the cultural and climatic shock was too much. When my seventeen-year-old daughter and I saw Jim's smiling face meeting us at the airport, however, all our apprehensions faded away. We no longer cared that it was too hot, that there were no sidewalks to walk on (as we were used to in our dear old Europe), and that the new world was looming large upon us. When Jim took us to our apartment and showed us the premises and the fridge (in which he had thoughtfully placed some much-needed fruit), we definitely felt at home. The next morning, Jim took us to buy the indispensable car, enroll my daughter in school, and we were all set. This is how Jim showed human warmth and friendship to people who, initially, were total strangers to him. Yet, not for long.

At university, Jim set me up in my office and introduced me to the WSB staff: Priscilla Letterman (Technical Editor) and two post-graduate students, as well as the Head of the English Department, faculty, and staff. It was all so cordial and calm that I felt I had come into a large family, which included Jim and his wife Darinda, as well as faculty members, including the late Douglas Brooks and Hilaire and Craig Kallendorf. At that time, Harry Meserole and his wife Dorothy were still around in this world, so I visited their home in Bryan (with Jim, who had great respect for his predecessor at the WSB), and admired the prize-winning orchids. All inspirational details that Jim set up as an academic and a friend (including the now-famous WSB dinner) speak for thorough academic discipline and warm humanity. "Don't worry about the boring work," he used to say when I tended to lose heart and be overwhelmed by the sheer quantity of books and articles to be reviewed and then entered in the WSB. It was all about discipline and good order, as I would later learn. Jim inspired a sense of self-control and hard work that would follow me throughout my life. Though words cannot capture the force of his presence, both personally and professionally, he is simply a living standard that I cannot forget. He is the reason for my love of Shakespeare and bibliography.

Now about Jim Harner's afterlives. Little would I know that the 772page Literary Research Guide - emblematically nicknamed "the Harner"would follow me throughout my academic career. When he modestly presented me with the impressive book, fresh from the press (third edition), I honestly

\footnotetext{
* Ovidius University of Constanţa, Romania.
} 
thought this was awe-inspiring. With his meaningful sense of humor, Jim said under his breath: "Don't you ever read it entirely!" The 1,207 entries with complete citations and descriptive annotations evaluating each work are entire worlds in themselves. Now, the huge volume is dog-eared from passing through the hands of eighteen generations (for each academic year) of Romanian students at Ovidius University of Constanţa - at first my undergraduate students in the academic writing course, the masters students, and later my doctoral students being instructed in research techniques for writing a dissertation. They are all acquainted with "the Harner" and my thankful voice is theirs as well. This is how Jim's life story lives on - through his family, colleagues, students, and friends. For Jim, his life and work were always in conversation with each other and he saw and did the best in both. He might like what he could see from Elysium: a place where one is said to meet ancestors, posterity, and afterlives.

\section{WORKS CITED}

Harner, Jim. Literary Research Guide. $3^{\text {rd }}$ ed. New York: The Modern Language Association of America, 1998.

\section{To a beloved Shakespearean friend (with yellow stripped tie)}

José Manuel González Fernández de Sevilla*

The final shadow that will close my eyes will in its darkness take me from white day and instantly untie the soul from lies and flattery of death, and find its way, and yet my soul won't leave its memory of love there on the shore where it has burned.

(Francisco de Quevedo, 1580-1645)

It was with great sadness that I heard that Jim Harner passed away. It was an irreparable loss for those of us who were privileged to know him and his astonishing editorial work. I found in him a shining example of how to follow one's own path, as he was not only a brilliant scholar but also a man of high ethical and moral principles, so kind and humble to acknowledge that he had made such an important contribution to Shakespearean studies. He remained grounded and with a common touch by shunning all hubris and pomposity that come as academics. However, Jim wearing a smart yellow stripped tie is the recurrent image that comes to my mind time and time again when I think of him.

\footnotetext{
* University of Malaga, Spain.
} 
I can't picture him in a different way. In his case, it was not sheer chance as yellow has been known the colour that signifies joy, radiance and friendship.

It was Jim who, in 1991, kindly invited me to be a contributor to the WSB. Though I did not expect it, I instantly confirmed my acceptance to work under his mastery and guidance. However it would take me some time to meet him in person. I still remember vividly my first encounter with him. It was in the WSC held in Valencia in 2001 when I had the privilege of meeting him not on the premises of the congress but in La Pepica, the famous Valencian restaurant, wearing, of course, his yellow stripped tie. This is another storyline of our future magic encounters in different SAA (Shakespeare Association of America), ISA (International Shakespeare Association), and WSC (World Shakespeare Congress) meetings all over the world, where he nicely played the host to WSB contributors. It is hard for me to understand that he will not be around anymore as it happened in the last WSC that took place in London last summer where his absence was very much felt. I particularly missed his masterful way of blending insightful comments into casual conversations.

I'm sure that Laura Estill and Krista May will be doing their best to continue with the legacy of a such a brilliant scholar whose memory will last for long among us. We must keep up with his commitment to the publication of WSB as it will be the best way to honour him and pay homage to a man who devoted his whole life to facilitating and advancing Shakespeare's scholarship all over the world. In this way, he will continue to lead and influence us by his example and work even long after departed.

Though it is hard to acknowledge he is no more with us, and we can no longer enjoy his company, he will live on in all of us that he touched in the many years of his long and productive life leaving warm memories alongside admiration. We will certainly remember Jim fondly and lovingly for years to come.

\section{Jacob Heil ${ }^{*}$}

\section{Remembering Jim Harner}

In the spring semester of 2006, Jim and his wife Darinda got a puppy. I know this - or, rather, I learned this fact back then-because Jim's feedback on my drafts, in addition to his trademark calligraphy, included specks upon specks of red wine. When, in our weekly meeting, he told me how their new family member had repeatedly knocked his glass, it wasn't to excuse the Jackson Pollock-ed draft he was returning but rather to revel in the new addition's spirit. I remember fondly his mock aggravation, a disingenuous performance that only underscored Jim's own jovial spirit.

\footnotetext{
${ }^{*}$ College of Wooster, USA.
} 
There is much in this memory that is at the core of the Jim Harner that I knew. There is the wine, of course: Jim was very gracious in sharing his knowledge on the subject and tolerating my enthusiastic naiveté. (In that respect, those conversations about wine were not, I suppose, unlike those we had about my dissertation.) This memory, though, also exemplifies Jim's generous affability. He cared a great deal to build relationships with his advisees, students, and associates, and he worked to build relationships among his expansive professional network. Sharing glimpses into his life beyond the office-like those of him and his puppy - are of a piece with the conviviality of the annual World Shakespeare Bibliography holiday dinner: all are about building otherwise superficial connections into professional relationships that have lives and arcs and meanings of their own. As a vocation, academia can be solitary and enervating; Jim taught me that it needn't — that it shouldn't— be so.

Perhaps it is because mine was one of the last dissertations that Jim supervised before his retirement in 2014, but he embodied, for me, a life-goalworthy work-life balance. He enjoyed good food and shared that passion by way of recommendation or, if one was a graduate student lucky enough to be at the same conference as he, by way of subsidy. He shared stories about his puppy and, eventually, his growing family. He taught me that intermingling the professional with the personal was not about letting the former encroach on the latter, but rather about allowing the latter to enrich the former. There should not be a complete overlap, of course, but buying an admired scholar coffee and bending her ear about how your research interests intersect is a fine way to further a research agenda.

As an incomprehensively knowledgeable scholar, Jim helped me become a scholar of early modern drama and dramatic authorship. I first "met" "Jim" in my first grad program at the University of Virginia, where we in David Vander Meulen's bibliography course referred to the Literary Research Guide as "The Harner." Working with Jim, I quickly learned that the actual Harner was a walking amalgam of the many editions of that guide, and he curated research suggestions with algorithmic effectiveness: "Oh, I see you're working on this topic. You may also like these resources." Perhaps more importantly, though, Jim helped me become a professional academic, an identity that, I can say without reservation, has led to me to where I am today. How grateful I am to have worked with him, to have known him, and to remember him, here and often. 


\title{
Epicurean Generosity
}

\author{
Julie D. Campbell ${ }^{*}$
}

First things first: Jim embodied excellence, professionalism, and kindness, and he helped his graduate students make sense of academia. He was an extraordinary mentor. Many colleagues who participate in this memorial endeavor will elaborate on those elements of working with Jim, and I would certainly second their words of praise. But here, I would like to share a few memories from my journals of Jim's generosity of spirit in the culinary realm because, in addition to reading and summarizing countless Shakespeare-related documents, working in the World Shakespeare Bibliography (WSB) included conversations about food and great restaurant experiences. Food was one of Jim's abiding passions, and he made sure that we, his staff, were well-fed and beautifully hosted whenever he had the opportunity to treat us.

On 14 November 1991, during my first year in graduate school at Texas A\&M, I wrote, "Dr. Harner keeps journals, too." Herewith, a brief selection of food and Jim memories.

In early December of 1994, I passed my preliminary exams. On 11 December, the day after our annual WSB holiday dinner, I recorded: "Last night Dr. Harner took us all to The Texan for great food-Caesar Salad you roll with your fingers, golden gazpacho that was delicious, and thick, tender steaks. He also made the opening toast a special one to congratulate me on the exams...." For those not familiar with the vagaries of the College Station, Texas, restaurant scene in the early 90s, The Texan was considered one of the most "gourmet" restaurants in town. Much of the food was very good, but with that good food, the chef had a strange tendency to serve canned green beans. That particular evening, however, Jim had ordered a feast for his party, which included the delicacies mentioned, as well as beautiful wines (I remember thinking the Chardonnay the most buttery I had ever tasted), and Dr. Harrison Meserole, our emeritus WSB director, provided orchids from his green house for each lady's place at the table. The holiday dinners were an annual feature of life in the WSB, and every year, Jim found a new and interesting place to take us. (Yes, even in Bryan-College Station, TX, even in the early-to-mid 90s. He was resourceful.)

Conferences were opportunities for restaurant exploration. Jim always did his pre-trip research. In March, 1995, we attended SAA in Chicago where we demonstrated the WSB Online for Cambridge University Press. Jim took the WSB group and the Cambridge representatives to a wonderful restaurant called Zinfandel. The food might be described as modern American cuisine; everything was imaginatively prepared and truly delicious - up to Jim's standards. A reviewer wrote, "We cannot think of another restaurant in these parts that

\footnotetext{
* Eastern Illinois University, USA.
} 
roots for the home cuisine like this place," and s/he raved about the "luscious sweets," including "butterscotch pudding" and "black-bottom-banana-cream pie," as well as the wine list with "no fewer than 24 Zinfandels, followed by an impressive collection of Cabernet Sauvignons, Chardonnays and Sauvignon Blancs" (Gayot). Our meal ended with WSB and Cambridge UP people, previously strangers to each other, passing an array of Zinfandel's famous desserts around the table and digging into shared plates without a qualm. Jim had that effect on people. When I ended up living in Illinois a few years later, I took friends to Zinfandel each time we visited Chicago, until the restaurant closed in 2002.

On 14 April 1996, just home from SAA in Los Angeles, I wrote: "Jim took us out Thurs. night for a gorgeous meal at the Water Grill-beautiful roasted salmon with fresh asparagus and basil-mashed potatoes, preceded by a shrimp-stuffed artichoke." I also noted that it wasn't until we were leaving the table after our rather loud, "gossipy, food-swapping meal" that we noticed a table of conference VIPs sitting behind us, where they had been dining in a quiet and dignified manner. Jim just smiled and waved genially.

On 27 March 1997, at SAA in Washington, D.C., I wrote that Priscilla Letterman (technical editor of the WSB) had asked Jim to take us to "a good French restaurant." So, he found one: Gerard's Place on $15^{\text {th }}$ Street. "It was wonderful — small, warm, elegant, with really good food." There was "asparagus with a paprika and parsley sauce," "a 'napoleon' of artichoke heart and foie gras," and "gorgeous halibut with wild mushrooms." For dessert, there was "chocolate terrine with lady fingers soaked in espresso" with "a coffee cream sauce." "Franglais at its most elegant," I said in my journal, clearly awe-struck and ready to re-tool as a restaurant reviewer if this whole job-search thing I was embarking on should flop.

On 15 June 1998, shortly before I moved to Charleston, Illinois for my job at Eastern Illinois University, I wrote that Jim took the WSB group "out for lunch at the new place, Clementine's.... It was terrific. Cream of red pepper soup, chilled shrimp, and a gorgeous berry Napoleon with fudge sauce." I also wrote, "They [the WSB-ers] are all so dear to me. I will miss our closeness very much, and will have to work hard to keep these ties going long distance."

Years passed. I saw Jim only sporadically because I began attending RSA more often than SAA, but he was always just an email away. In April, 2010, the stars aligned. I was going to be in Chicago to give a talk at the Newberry with my co-editor on a book project; Jim was going to be there for a conference. I had recently been promoted to full professor and saw my chance to take him out for a meal to say a heart-felt thank-you for all his years of mentoring, not to mention all the wonderful meals. I made a reservation at Blackbird, a restaurant rife with James Beard Awards and well-known for its "elegant and imaginative Midwestern cuisine" (Blackbird). It seemed the perfect place to take Jim. And it was, except...he wouldn't let me. 
When I arrived at the restaurant, he was already there; he had already secured the table and ordered a bottle of water. We had a great lunch-I forget exactly what we had, and I didn't write it down, but I know it included their famous salad of endives, baby lettuces, pancetta, and a lightly poached egg, served in a carefully molded structure of crisp shoe string potatoes that the waiter breaks open for you at the table-impressive and delicious. We talked and talked. When it was time to go, the waiter brought the check and did not hesitate for a moment. He handed it straight to Jim. I protested that it was my treat, that it was my big chance to say thank you. I protested urgently. Jim clutched the bill to his chest. He counter-protested loudly. People started looking at us. The waiter came back over. Jim shoved a credit card at him. I finally caved and thanked him profusely. Then, we took a taxi to our respective next stops. We reached mine first, and Jim wouldn't let me pay for that either. The cab sped away.

That was Jim, a person of great generosity, a lover of fine food, and a profoundly gifted mentor. I'm grateful that I got to say thank you, even though I didn't get to treat him to lunch.

\section{WORKS CITED}

Blackbird. http://www.blackbirdrestaurant.com/\#new-page Gayot: The Guide to the Good Life. "This Restaurant is Closed: Zinfandel." http://www.gayot.com/restaurants/zinfandel-chicago-il-60610_5ch99148.html.

\section{Youmi Jung ${ }^{*}$}

\section{Jim Harner's Generations of Influence}

Meeting Dr. James Harner for the first time in person and knowing that I was assigned to work as a research assistant for the World Shakespeare Bibliography as my first year doctoral assignment at Texas A\&M University was terrifying and exciting at the same time. To be honest, I was more terrified than excited. His name and scholarship, not to mention the MLA's Literary Research Guide, have always been a big part of bibliography classes I took since I started to major in English, and the World Shakespeare Bibliography has been the database I've used for years. On top of that, it was the year when I started my $\mathrm{PhD}$, and my very first year in the United States - one Pacific Ocean and several states away from Seoul, South Korea where I was born and raised. I was terrified to work with such a great scholar because I did not want to mess this up and disappoint him.

\footnotetext{
* Texas A\&M University, USA.
} 
After only a few moments of meeting with him and running into him in the hallway, however, I realized that he is a very generous and thoughtful mentor Jim, not just the renowned scholar Dr. Harner from my Bibliography and Research Methodology syllabus. I was on my way to class one day in 2013, feeling frustrated for not being able to express my thoughts well in class discussion. Jim was passing by and noticed immediately that I was not in my best mood. After listening to my concerns for a few minutes, Jim shared stories of his former Korean students who got their PhDs from the program. Instead of just patting me on the shoulder and telling me that things will get better, Jim reminded me of how I was continuing important line of South Korean English literary scholars who began their academic career in the English department at Texas A\&M University. One of them was my MA thesis advisor from Seoul National University in South Korea, Dr. Hyonjin Kim, prominent medievalist and Arthurian literature scholar in South Korea. He graduated from our program in 1999 and took Jim's bibliography class when he was in graduate school. It was actually in Dr Kim's class that I first learned about bibliography and read Jim's Literary Research Guide. Jim's encouraging words made me think how my MA thesis and research I had done until then were directly and indirectly influenced by decades of tradition of Korean scholars from our program and how I was about to continue that line of scholars. I then realized how I was fortunate to know and work with Jim and be part of the tradition, which motivated me to power through my first year as a $\mathrm{PhD}$ student.

To this day, I often think of Jim's influence on my career as a literary scholar and his expansive legacy. My academic career was conceived under his scholarship and generations of mentorship. I was very blessed to have known him in person and worked with him for one short year, and I feel sorry for other graduate students and young scholars who will not have the opportunity to work with him; but I believe that his scholarship and mentorship will continue to have lasting influence on generations of literary, bibliographic, and Shakespearean scholars around the world.

Nicole Hagstrom-Schmidt ${ }^{*}$

\section{Tea at the Folger}

I first met Jim Harner in 2014 when I was visiting Texas A\&M University. It was February during the coldest winter that I can remember, not that any of that mattered in Texas where the sun beamed all week and the undergraduates had already begun sporting shorts and oversized cotton t-shirts. During the

\footnotetext{
* Texas A\&M University, USA.
} 
second day of my trip I was whisked about the Liberal Arts, Arts, and Humanities Building with most of my time spent on one fourth floor corridor where the World Shakespeare Bibliography now resides. Jim was one of the last people I was scheduled to see before debriefing with the graduate director and heading off to Houston to catch my flight back to Illinois.

Jim was in his new office, prime real estate in admittedly one of the nicest buildings ever to house an English department. His office was at the end of the hallway and twice the size of most of the offices in the building, complete with a small round table and chairs as well as a giant U-shaped desk, a wall full of windows, and, of course, shelves and shelves for books. I recall that the shelves were remarkably bare for a professor, but it was 2014 and he was set to retire in the new year. He invited me to sit at the small table and began to talk as if I were already in the department.

I cannot tell you exactly how or why it happened, but something clicked with me that day when I met Jim Harner. Perhaps it was the way he gave advice. Not, "You might try this," but "When you do this." Perhaps it was the way he lowered his voice to a whisper and conspiratorially told you what sounded like the biggest kept secrets in the world. Or maybe it was the way he casually pointed out the turkey vultures outside the window. I am not sure, but something in his speech, his manner, reminded me of my East Coast feminist grandmother. I suddenly relaxed and became far less reserved than I had in the previous meetings where I was trying so hard to sound smart and mature.

After matriculating at Texas A\&M, I had only one semester to get to know Jim. Yet in that limited amount of time we managed to connect and develop one of the most supportive mentoring relationships I have ever had. Three weeks into my first semester I had my first real "bad day"- the type of day where the loneliness and imposter syndrome really set in. On that day I wandered into the World Shakespeare Bibliography office to pick up some book collections to annotate. Jim's door, just down the hall, stood open. "I'm going to talk to Jim," I told myself.

For his part, Jim seemed pleased to have company. He had just finished teaching a large undergraduate Shakespeare survey and was holding office hours. We chatted mostly about his trips to Washington, DC where he spoke fondly of the Folger Shakespeare Library and the Library of Congress. Then, his voice dropped, he looked around conspiratorially, and then said, "You need to go to tea at the Folger." He would repeat this advice no less than four times during our brief time together even after he retired.

We continued to have chance meetings throughout the semester, though the majority of those seemed to coincide with days that I needed just a little extra push to keep going. Jim, for me, was the effortless mentor who managed to reassure and motivate without relying on any sort of gimmick or conventional 
cheerleading. He was positively understated, occasionally dropping what one of my colleagues referred to as "truth bombs" about succeeding in the profession. His advice has stuck with me all throughout graduate school. Whatever he said, I did. He told me to go study at the Folger. I did. He told me who to put on my committee. I did. He told me to write three articles before going on the job market. I...am working on that. And, of course, "Go to tea when you're at the Folger." I did, because it is excellent advice.

That Jim could have such an impact on a person who knew only briefly him speaks volumes about his remarkable abilities as a mentor. Despite the tooshort amount of time we spent together, Jim Harner remains one of the most influential and impactful mentors that I have ever had. He was a central reason for my choosing to attend Texas A\&M for graduate studies due in part to his impact as a researcher and influence in bibliographic methods, but also due to his uncanny ability to simply say what needed to be said at the moment where I was most able to hear it.

\section{Jim Harner's Legacies}

\section{Laura Estill ${ }^{*}$}

When I first came to Texas A\&M University for a campus visit for a position in "Digital Shakespeare Studies," I knew Jim Harner only by reputation. I knew him as the person who wrote the MLA's Literary Research Guide. I knew him as editor of the World Shakespeare Bibliography (WSB, www.worldshakesbib.org). Today, I remember him not just as a preeminent bibliographer and Shakespearean, but as a friend and colleague.

Jim's work was foundational to the study of English literature. Although the MLA no longer hosts the Literary Research Guide, Andrew Pilsch has made a copy of the sixth edition available at https://oncomouse.github.io/literaryresearch-guide/. I still have my now out-of-date print copy on the shelf: this volume was jam-packed with so much information that it only made sense to make it searchable online. The Literary Research Guide was named one of the Times Literary Supplement's books of the year in 2008; it won a number of other accolades including the American Publishing Association's Best Humanities Electronic Resource. This book is taught around the world in research methods courses, where, as others have related here, it is often known simply as "The Harner." Although Jim is no longer with us, his important contributions to bibliography and literary studies live on.

\footnotetext{
* St. Francis Xavier University, Canada.
} 
As editor of the World Shakespeare Bibliography for thirty years, Jim's contributions to Shakespeare studies in particular can hardly be understated. As many before me have noted, enumerative bibliography can be a thankless and, in the case of an ongoing project like the WSB, unending task. Yet the rewards to field are incalculable: the WSB offers Shakespeareans a resource that is the envy of scholars working on other literary authors.

Though Jim was not the creator of the WSB, it was under his editorship that the WSB first went digital: first, to CD-ROM, and then, online. Jim's innovation allowed researchers to find information on publications and performances across years: previously, scholars had to search a print bibliography for every year if they wanted information about publications on a particular play or topic. With Jim at its helm, the WSB won the British Library Association's Besterman Medal for outstanding bibliography (1997) and the BestermanMcColvin medal for outstanding reference work (2001). Jim was the person who began annotating digital projects for inclusion in the WSB. The World Shakespeare Bibliography grew by almost 100,000 annotated entries and hundreds of thousands of reviews when Jim was editor.

I was hired to take Jim's position as WSB editor. In just two years, Jim taught me more about enumerative and annotated bibliography than I thought it was possible for one person to know. With the WSB editorship came lists of databases, journals, presses, call numbers, and resources to be searched and kept up-to-date. Suddenly, with Jim's guidance, I had my finger on the pulse of Shakespeare studies: it was both exhilarating and exhausting (and, frankly, still is). Jim has left big shoes to fill: his standards of scholarly excellence are those to which I aspire.

The best part of becoming editor of the WSB was more than the academic side of things, however; it was getting to know Jim, Krista May (WSB associate editor), and the international community of scholars who comprise the WSB's committee of international correspondents. I loved going to the 2014 Shakespeare Association of America meeting in St. Louis, where Jim introduced me to dozens of Shakespeare scholars, most of whom I knew only by their scholarly reputations. 2016 marked my first World Shakespeare Congress, where I was able to meet even more scholars that I had only ever met via email before. To this day, there are still many WSB contributors that I have never met in person, but that I am proud to count as my colleagues because of the time and commitment they make to the WSB. Jim fostered an academic community in which I am honored to be a part.

Jim built community by being patient, kind, and caring. He was known in our department as a generous teacher who got to know his students: he ran a "lunch lottery" and took students out to lunch over the course of the semester. Jim supported his younger colleagues (including me!) by reading drafts of our work, encouraging us to apply for awards, and writing reference letters. He was a smiling presence in the department. 
As part of his community-building, Jim celebrated the wonderful milestones that the WSB achieved and the people who made them possible. One of my favourite memories of Jim will always be the 2014 WSB holiday dinner. I was due to have my first baby in December of that year, so we planned to have our holiday dinner in mid-November to celebrate the work and achievements of the College Station-based WSB team. My son arrived a month early, to everyone's surprise, in the week before our dinner. Jim was genuinely thrilled when we brought our newborn to the fanciest restaurant in town-Jim was a notorious foodie who loved the best of the best. Having come earlier than expected, my baby was less than six pounds, but he looked especially small when cradled gently in Jim's arms. (Jim was former high school football player, tall and broad-shouldered.) Jim held this days-old sleeping infant and just smiled beatifically. Later, he suggested that I bring a pack'n'play into work so the baby could play and hang out in the office. When he retired, Jim moved to Virginia to become a full-time grandfather.

I miss Jim Harner and am fortunate that I had the chance to know himand not just because he always had recommendations for the best restaurants and bookstores. Thank you, Jim, for being a great bibliographer and researcher. Thanks most of all for being so kind and welcoming. I can only hope that, as editor of the World Shakespeare Bibliography, I continue your legacy of academic excellence and fostering community. 